\title{
Changing the library brand: a case study
}

\section{Ben Wynne, Simon Dixon, Neil Donohue \& Ian Rowlands}

Acceptance date for publication in the New review of academic librarianship: 16 February 2016

The pace of change in higher education is increasing rapidly, creating both opportunities and challenges for developing the role of academic libraries. Taking the University of Leicester in the UK as a case study, this article illustrates how libraries are adapting to this environment by changing the library 'brand' and considers how customers are responding to this re-positioning.

\section{A changing environment}

In a report on the future of research libraries, the United States based Council on Library and Information Resources (2008) outlined major, on-going change in how research is conducted and research findings communicated. Interdisciplinary and collaborative research is long established in the sciences but also increasingly commonplace in the humanities and social sciences. Digital technologies are enabling researchers to pose new research questions and to develop new research methodologies - a process often referred to as 'Digital Scholarship'. There has been a vast increase in the volume and diversity of research outputs being created, analysed and shared amongst researchers. A recent NMC Horizon report (2015) highlights the growing diversity and complexity of the scholarly record being created. Lavoie and Malpas of OCLC (2015) have proposed a framework to further understanding of the nature of this dispersed, complex, digital scholarly record and the challenges it poses for libraries - individually and collectively - if they are to have a role in providing access to and preserving scholarly information resources for the long term.

A combination of technology and growing expectations from research funders to maximise access to published research findings, is also leading to major change in how formal publishing is paid for and the library's role in relation to publishing. Major shifts are taking place in many subject areas from a 'reader pays for access' to an 'author's institution or research funder pays for publication' model - thereby providing 'Open Access' (i.e. free to the end user) to research outputs. This has been accompanied by moves to make research publications as freely re-usable by others as possible. Archambault et al (2014), in a report for the European Commission, estimate that more than $50 \%$ of scientific papers published 
between 2007 and 2012 are freely available to anyone with access to the Internet. This shift is changing, in turn, where libraries sit within the formal publication chain - maintaining a traditional position at the end of the chain by providing post-publication access, whilst also developing a position at the start of the chain by providing services to help authors navigate the Open Access options available to them at the point their manuscript is submitted to the publisher.

The increasingly competitive nature of higher education research internationally, illustrated by the growing importance of 'league tables' such as the QS World University Rankings, is also leading universities to plan and manage their collective research effort much more actively in order to maximise performance. This has brought the skills of the bibliometrician (i.e. skills in compiling and analysing citation patterns between research outputs) central stage. Many libraries now provide expertise in citation analysis and managing the institutional publication record to inform research strategies, grant capture and to support compliance with funders' publishing policies.

Learning and teaching are also changing. Although writing over 10 years ago, Allan's (2003, p2) picture of both being transformed by technology, changing patterns of work and leisure, globalization and learners' rising expectations remains true. Freeman $(2005$, p.2) argues that the library must accommodate these changes and ensure that it meets the changing goals of its institution. Library space is being used to support new pedagogies - such as a much greater emphasis on collaborative and interactive learning methods - and its virtual space to deliver content and support to learners at point of need. In an age when information is readily available to most people, Walton and Cleland $(2013$, p22) note research findings which suggest that libraries need to be part of helping learners to develop critical thinking skills to engage with information effectively rather than focussing on skills in using specific information resources.

Significant though these changes are for the library, they do not alter its nature as a means of providing access to information and sharing of knowledge - even if this function is now dominated for most people by the Web search engine. Even more significant, perhaps, are the opportunities arising from Digital 
Scholarship for the library to become an active partner in the creation as well as the dissemination of knowledge.

Drawing on the strength of Digital Humanities at the University of Virginia, Nowvinskie (2013) argues that the library is well placed to be an equal partner with academic staff in Digital Humanities research - with one of its strengths being an ability to sustain innovations due to long experience of developing and maintaining services. While outlining the challenges of defining and sustaining services to enable Digital Scholarship at New York University, Vinopa (2013) also illustrates the scale and sophistication of the digital services already provided by its library including services for data analysis, digitisation and preservation. In this environment, Vandegrift $(2013$, p69) notes the potential for "exciting new ways for scholars to work with libraries, not just in them".

Stoffle $(2008, \mathrm{pp} 5 / 6)$ argues that the library needs to become "a place for the production of knowledge" - a place for using new tools and new ways of disseminating knowledge - and the necessity for the library to collaborate with internal and external partners to achieve this. She sees financial pressures rather than technology as being the primary driver of change, arguing that the continually rising costs of creating and maintaining 'collections' cannot be sustained given the resource constraints within higher education. The opportunity for the library lies in managing and developing the information resources being created within its own institution. In a later article, Stoffle (2011, p137) emphasises that continually improving and developing needed new services must now be the library priority, not 'collection'.

The rare and unique resources held by many libraries are, however, asserting a growing importance demonstrating that, at least in this respect, the local library collection remains relevant. Adopting the term 'unique and distinctive collections', Research Libraries UK (2014) has highlighted the growing potential of collections held by its members to contribute to their institutions' distinctiveness in the eyes of potential students, staff and donors. 


\section{Marketing and libraries}

While exploring the opportunities arising from this changing environment for libraries, the Council on Library and Information Resources (2008) also notes the risks to the library of continuing to be primarily associated with providing collections of books and journals as this becomes more and more of a 'niche' activity. Reporting on a survey of UK academic staff conducted in 2012, Ithaka S\&R (2013) noted that almost all respondents viewed the library's primary role as being a purchaser of information resources. Saunders (2015) reviewed the strategic plans of major research libraries in the United States and found surprisingly limited mention of development of new services for Digital Scholarship. Grant $(2015, \mathrm{p} 100)$ cites an OCLC survey of 2010 in which $75 \%$ of respondents said that for them the library brand was 'books'.

Brand is, of course, a marketing concept and even a partial review of the literature demonstrates that the marketing of libraries has a chequered history. Garoufallou (2013, p313) describes marketing as a "customer-oriented strategic management process" which enables the development of quality products and services which meet customer needs. Germano (2010), however, notes that librarians have often confused marketing with promotion - which forms just one part of the marketing process. Polger (2013) provides a literature review with many examples of articles on marketing in libraries which illustrate the confusion between marketing and promotion; in addition, the review illustrates how some librarians can be uncomfortable with the term marketing as it is associated with 'commerce'. Reporting on a small survey of UK academic library staff, Estall $(2011$, p203) found that most respondents had a positive view of marketing but there were misunderstandings about what it meant and some associated it with a "cut-throat world of competition". This view is reflected by Clark $(2009, \mathrm{p} 97)$ who views marketing as an inappropriate response to the 'library's certain demise', arguing instead for advocacy of the library's public benefit.

Germano $(2012$, p79) argues that to be successful marketing must be an integral part of the strategic planning process. There needs to be a clear vision for the service which is validated by an understanding of customers' needs and what is of most value to them. To achieve this understanding requires "market research, consumer behavior research, market planning, new product/service development processes and 
personal selling" - capabilities which are often lacking, leading to 'ad hoc' approaches. Kendrick, in an interview reported by Potter (2012), expresses the view that strategic marketing is often not done well or at all by libraries because it requires significant resourcing. Marketing, he continues, needs to be planned, sustained and overseen consistently to achieve results. Robinson $(2012, p 7)$ sees successful marketing as requiring a "marketing orientation" by the entire service and this requires cultural change in libraries.

Wade (2012) provides a powerful example of the potential of marketing when fully implemented, outlining how the development of a marketing function at the National Library of Scotland from 2004 onwards, which included an extensive programme of customer research and stakeholder engagement, enabled the library to position itself as integral to education, research and increasing understanding of Scottish culture. Membership and use more than doubled and political support for the role of the library increased. He concludes by arguing that the opportunities for libraries far outweigh the threats during "one of the most exciting and challenging times there has ever been for librarians".

\section{University of Leicester}

The University of Leicester is a medium sized, research-intensive university in the English East Midlands, approximately one hundred miles north of London. In full-time equivalent (FTE) terms, the University has approximately 16,000 students and 3,000 staff, of whom 1,500 are on academic contracts. Both research and teaching are equally important. There is a diverse student body and a broad portfolio of subject programmes - with large numbers of students from outside the EU and distance learners.

In $2015 / 16$, the Library had 71.5 FTE staff and a budget of $£ 6.9 \mathrm{~m}$, of which $£ 3.9 \mathrm{~m}$ was allocated for information resources. All the physical resources and services are provided from one building which reopened in 2008 after extensive refurbishment and enlargement. Spending on and use of digital library resources and services dwarfs use of physical collections and services; in 2014/15, for example, members of the University each downloaded 278 eBook chapters, on average, while they borrowed 13 print books. 
The service has achieved good satisfaction ratings in the UK's national student surveys in recent years with a 91\% satisfaction rating in 2015. The library achieved the UK's Customer Service Excellence award for public services in 2010, which has since been re-accredited twice. Use of the resources, facilities and services has increased steadily in recent years, reflecting the experience of many other UK academic libraries. In many respects, therefore, the library is the most successful it has ever been demonstrating, as noted by Freeman $(2005, \mathrm{p} 2)$, that libraries are benefiting from the rapid expansion of the digital environment, rather than being threatened by it.

\section{Re-shaping a library}

The on-going change in how research and learning take place and the growth of digital technologies are having a major influence on what services the library provides and how.

Following the redevelopment of the library building in 2008 , which was largely driven by the needs of taught course students, attention shifted to improving services for the research community in the light of the University's growing research portfolio and increasing numbers of research students.

The library had operated a 'subject librarian' type staffing model successfully for many years with librarians assigned to understanding and meeting the information needs of students and staff in specific academic departments. These roles were, however, increasingly difficult to sustain, particularly in relation to research. It was not feasible for every subject librarian to develop expertise in the rapidly changing world of scholarly communications whilst also working with academic departments on meeting the needs of their fast changing teaching programmes. Each subject librarian also tended to approach their role from a position of autonomy, based on a culture in which they were seen as the 'expert' for their particular area. This led to an environment in which it could be difficult to develop and sustain team objectives and collaboration, with shared working often needing to be 'negotiated'. During 2012 a new structure was, therefore, introduced based on functional specialisms and team working. 
A 'research services' team was created to focus on researcher development, the use of bibliometrics to inform individual, group and University research strategies and grant capture and development of services to support Open Access, including the management of an existing 'institutional repository' of University theses and research papers. A small Archives \& Special Collections team was strengthened by the creation of a full time post to manage this area which was also given a remit to develop the library's contribution to Digital Humanities. Finally, a 'learning and teaching services' team was given the remit to further develop the library's contribution to learner development and formal communication channels with each of the academic departments. Although there were similar developments at other UK university libraries at about the same time, the restructuring was primarily influenced by an assessment of where the needs and opportunities lay locally.

An important aspect of the restructuring was the opportunity to recruit new staff as well as for existing staff to develop their skills in new or revised roles. Some of the new staff did not come from formal library backgrounds but from research backgrounds of different kinds; this has greatly strengthened the library's ability to develop its services for the research community.

Although the total staffing complement across the three teams differed little from previous arrangements (approximately $14 \mathrm{FTE}$ ), the clearer focus for each team has led to an increase in the range of audiences reached and breadth and depth of services provided.

The creation of the research services team put the library in a good position to respond to new Open Access policies in the UK, establishing processes to support Gold Open Access publishing relatively quickly, increasing support for Green Open Access and leading the development of University policy on Open Access. This team has also led the library's contribution to supporting effective research data management, largely driven by research funders' requirements in this regard.

The visibility and role of the Archives \& Special Collections has also increased significantly. The association 
with Digital Humanities opened doors to academics in the arts and humanities, in particular. Library staff now collaborate regularly with academics on funded humanities research projects. The contribution to projects includes expert advice on the completion of technical plans required by funders, the use of Library supported platforms for managing digital assets, creating metadata, complying with copyright and managing feasibility projects associated with larger programmes of research. These activities have increased the reach of Archives and Special Collections, engaging new audiences with the Library's unique and distinctive collections.

The creation of digital content also supports teaching and there has been a strong emphasis on building relationships with departments with teaching interests in areas covered by collections, and through outreach events. All first year undergraduate History students, for example, are now introduced to the Archives and Special Collections as part of a re-design of the curriculum intended to increase students' engagement with primary research resources.

\section{Re-positioning a library}

The library of the University of Leicester is, therefore, moving towards the type of services envisaged by Stoffle (2008), Nowvinskie (2013) and others with a much greater emphasis on partnering with academic staff on the creation and dissemination of knowledge and the curation and exploitation of information resources created within the institution.

Nonetheless, the scale of activity by the new teams is dwarfed by the high volume services of the library which necessarily continue to be centred on the provision and management of learning spaces and access to published content. It is a considerable challenge to extend what services academic and professional services staff associate with the 'library' beyond 'books' and the procurement of content as illustrated by Ithaka S\&R (2013) and Grant (2015).

The library undertakes a customer satisfaction survey every three years using the LibQUAL methodology 
developed by the Association of College \& Research Libraries in the United States. The most recent survey was conducted in November 2014. This demonstrated that academic staff were the most demanding and also the most dissatisfied of the library's primary user groups (the others being defined as undergraduate students, taught postgraduates and research students ) - with their dissatisfaction centring on access to digital information resources which did not meet their minimum service expectations. This was also the case in the 2011 survey - although the position had improved by 2014.

These findings led to a focus group with academic staff drawn from different levels of seniority and subject areas. These were all individuals with whom the library had some existing relationship and who were well enough disposed towards the library to give their time to a focus group; nonetheless, a number of them considered themselves to be 'non-users' as they never used the physical building. The discussion about access to information resources for research and teaching was broad ranging and clearly demonstrated that the problems lay not in major gaps in the range of digital information resources available but in the arrangements in place for authenticating access to them from outside the University network; these were seen as too complex. This outcome led to specifying a project with the University's IT Services department to improve the arrangements. The discussion also illustrated that some of those present - who had some experience of collaborating with the library on creating and using digital information resources for their research or teaching - felt that there was very limited awareness amongst academic staff of these newer ways in which the library could enhance their teaching and research.

\section{Beginning a strategic marketing approach}

Following the restructuring of 2012, we began to review and develop our approach to 'marketing'. While the restructuring was a response to clear opportunities to improve services for learning and research, limited time had been given to really understanding the needs of different user groups.

The library had been fairly typical of the approach outlined by Germano (2010), and many others. The word marketing was used to describe what was largely promotion. These activities were, however, 
increasingly planned, targeted at particular user groups and structured around the academic cycle and the changing needs and priorities of students and staff at different times.

A communications remit was added to an existing post and a cross-service 'Marketing \& Communications Group' put in place to develop and manage the delivery of a communications plan with a number of regular campaigns targeted largely at taught course students and including such topics as 'succeeding in your dissertation' and 'getting into the study zone' (at examination periods).

These campaigns were often associated with initiating new services such as creating a suite of online resources to support dissertation students and enabling students to request and receive new books directly and quickly. These developments brought some success with students' satisfaction rating with the library in the UK's national student survey reaching its highest ever level to date at $92 \%$ in 2014 .

At the same time, a more systematic approach was taken to gathering and analysing data about the use of library resources and services in order to gain a better understanding of who was, and wasn't, using the library and how.

This led to some unexpected insights such as that while students in scientific subjects borrowed very few physical resources per head, they were amongst the highest users per head of the library as a learning space. An analysis of use of digital resources established that campus based and distance learning students made comparable use of the digital resources but there was also a significant number making no use of them.

Analysis also confirmed much that was already known, most notably that academic staff in scientific subjects made no use of the library building and the physical collections and, even for academics in the arts and humanities, such use was at very modest levels. It also demonstrated the rapid increase in use of digital resources across almost all subject areas far outstripping use of the physical collections which had 
also begun to decline.

The data analysis also informed the creation of personas for different 'customer segments' which were based on academic roles i.e. undergraduates at different levels of study, taught postgraduates, research students, early career academic staff and established academic staff. This process proved helpful in beginning to focus library communications much more on the benefits to different users of a particular service rather than its features.

During this period learning from the outcomes of the restructuring of 2012 , as well as the continuing change in how research and learning were conducted in the University, increased our ability to see and develop opportunities for piloting and developing new services - particularly for staff. This included beginning to develop a role in research data management, advising on options for publishing research outcomes, piloting a journal publishing platform and developing greater collaboration between librarians, learning technologists and educational designers in curriculum development.

A marketing consultant was commissioned, not to create a marketing plan for our changing library, but to develop and deliver a number of workshops to take members of the Marketing \& Communications Group through the marketing cycle and tools and techniques in order to enable a more strategic, planned and evidence based approach to the development of particular customer segments. A major example was a campaign to raise awareness of academic staff of the benefits and official requirements for ensuring Open Access to their research outputs; this led to the number of articles deposited in the University repository increasing by over 200\% between 2014 and 2015.

This process was practical and influential in shifting our shared thinking beyond 'promotion' to understanding how integral marketing is to strategic development. It also illustrated, as noted by Kendrick quoted by Potter (2012), how intensive the marketing process can be, suggesting once again, perhaps, why it has often be only partially implemented by libraries. 


\section{New University strategy}

In 2014, the University appointed a new President and Vice Chancellor. This, not surprisingly, was the impetus for the University to review its strategic direction and priorities, a process which culminated in a new strategic plan by the summer of 2015 .

There were several opportunities for library staff to contribute to this process, in particular for the University Librarian. This led to the University making a number of significant commitments of direct relevance to the kind of library it would need for the future, most notably commitments to Open Scholarship, to offering a much greater variety of learning spaces and opportunities for its students and to furthering its role in community engagement and increasing understanding of the cultural heritage of its region.

A parallel process with library staff led to clear identification of the opportunity to extend the library's role by re-positioning it as a proactive partner and collaborator in the creation and dissemination of knowledge - drawing on the unique set of information skills and expertise which the library could offer and develop within the University. The curation of valuable research data, the exploitation of unique and distinctive collections for research and learning, the management and re-use of the huge variety of learning resources created within the University are all examples of the existing and new opportunities identified. This outcome could be seen as being partly a result of what had been learnt and achieved since 2012. It was also an indication of how aware staff were of how much more needed to be, and could be, achieved in developing the library's role.

The work of the Marketing \& Communications Group was part of this strategic planning process. Whilst recognising the importance of the library engaging effectively with students, there was clear agreement that academic staff were the priority when it came to the desired re-positioning of the library and that this 
was where strategic marketing efforts needed to focus. There was also clear agreement that while there would continue to be a rolling communications plan, marketing needed to be integral to development of the emerging library strategy rather than having a separate 'marketing strategy'.

\section{Continuing staff perceptions}

Many academic and professional services staff remain unaware of the new library services increasingly available and continue to associate the word 'library' entirely with the traditional areas of getting access to a book or journal or providing quiet study space for students.

However, within a few years the boundaries of the 'library brand' have extended for many staff as evidenced by the growing number and range of interactions between them and library staff.

One of the most powerful means of changing perceptions has been practical demonstration of new approaches and possibilities which then influence how a growing number of people perceive the role of the library. Some of these have already been outlined above; applying expertise in bibliometrics to advise individuals, groups and senior managers on research strategies and to enhance research bids; partnering with academic staff on funded research projects; engaging undergraduate students with primary research materials in collaboration with academic staff.

Some of the practical results of this 're-positioning by doing' are that the library has increased its integration with and influence in the University. It is an active contributor to more University committees and decision making meetings than it was in 2012 - across learning, research and institutional planning. It has much more developed relationships with other professional services, most notably the University researcher development team, the Research and Enterprise Division and the learning development team as a result of working together on areas such as research grant capture, reporting on institutional performance, research assessment and curriculum development. This has led to growing shared understanding of our different areas of expertise, leading to more sustained collaboration for mutual 
benefit and, as a result, more effective shared support for academic staff and students.

What has also become apparent, as these relationships have developed, is how influential the politically disinterested, interdisciplinary nature of the library as a central unit supporting all subject areas can be. For example, library leadership of a Digital Humanities Advisory Group was welcomed and preferred to academic leadership. When a recent decision was made to establish a research data management service for the University, senior academic staff wanted the library to lead it.

Another powerful demonstrator of the gradual shift in how the library is perceived has been the outcomes from the process which culminated in the University's new strategic plan. The plan's clear commitments to Open Scholarship, to providing a greater diversity of learning opportunities and spaces for students, to raising the profile of the University's community engagement and cultural heritage initiatives have already been noted. The library was influential in shaping some of the thinking which led to these commitments and they now offer major opportunities to position the library as an active partner in the knowledge creation and dissemination required to meet them.

\section{Conclusions}

While much remains to be achieved in extending the library brand, an infrastructure is now in place in terms of people, technical systems and relationships which did not exist previously and which is enabling the library to increase its role and relevance.

Relationships between library, academic and professional services staff have been and will remain fundamental to what can be achieved. This raises challenges in terms of scaling up and how our reach can be further extended.

Working with a marketing professional has increased our understanding of how to define, understand, prioritise, design and measure services for different user groups - recognising that it is not possible or 
necessary for us to maximise a position with all our potential users to achieve success. It is in this context that we have confirmed the fundamental importance of changing the perceptions of academic and professional services staff in order to extend the library brand.

As part of this continuing process, we have recently created a new, full time, role devoted to marketing by re-allocating existing resources. This post will provide more time and expertise to work with managers to further develop an evidence-based, sustained and targeted development and promotion of new and existing services.

\section{References}

1. Allan, B. (2003) Blended learning: tools for teaching and training. London, Facet

2. Council on Library \& Information Resources (2008). No brief candle: reconceiving research libraries for the 21st century. Washington DC: the Council.

3. Archambault, Eric at al (2014). Proportion of Open Access Papers published in peer-reviewed journals at the European and world Levels-1996-2013. Montreal: Science-Metrix. Retrieved 1 Feb. 2016 from http://science-metrix.com/files/science-metrix/publications/d $1.8 \mathrm{sm}$ ec dg-rtd proportion oa 19962013 v11p.pdf

4. Clark, S. (2009). Marketing the library? why librarians should focus on stewardship and advocacy. Progressive Librarian, (33), 93-100.

5. Estall, C. \& Stephens, D. (2011). A study of the variables influencing academic library staff's attitudes toward marketing. New Review of Academic Librarianship, 17(2), 185-208.

doi:10.1080/13614533.2011.610217

6. Freeman, G.T (2005) The Library as place: changes in learning patterns, collections, technology and use. Washington DC, Council on Library \& Information Resources. Retrieved 1 Feb. 2016 from http://www.clir.org/pubs/reports/pub129

7. Garoufallou, E., Siatri, R., Zafeiriou, G. \& Balampanidou, E. (2013). The use of marketing concepts in library services: A literature review. Library Review, 62(4), 312-334. doi:10.1108/LR-06-2012-0061

8. Germano, M. A. (2010). Narrative-based library marketing. The Bottom Line, 23(1), 5-17. doi:10.1108/08880451011049641

9. Germano, M. A. \& Stretch-Stephenson, S. (2012). Strategic value planning for libraries. Bottom Line: Managing Library Finances, 25(2), 71-88. doi:10.1108/08880451211256405

10. Grant, C. (2015). It's time to define a new brand for libraries. Let's make sure it leaves people soaring, not snoring. Public Library Quarterly, 34(2), 99-106. doi:10.1080/01616846.2015.1036703

11. Ithaka S+R, Jisc and RLUK. (2013). UK survey of academics, 2012. New York: Ithaka S+R. Retrieved 1 Feb. 2016 from http://www.sr.ithaka.org/publications/ithaka-sr-jisc-rluk-uk-survey-of-academics-2012/

12. Lavoie, Brian and Constance Malpas. (2015). Stewardship of the Evolving Scholarly Record: From the Invisible Hand to Conscious Coordination. Dublin, Ohio: OCLC Research. Retrieved 1 Feb. 2016 from http://www.oclc.org/research/publications/2015/oclcresearch-esr-stewardship-2015.html

13. >LibQUAL+: charting library service quality. Retrieved 1 Feb. 2016 from http://www.libqual.org/home 14. NMC Horizon Report, 2015 Library edition. Chur: New Media Consortium, University of Applied Sciences. Retrieved 1 Feb. 2016 from http://www.nmc.org/publication/nmc-horizon-report-2015-libraryedition/

15. Nowviskie, B. (2013). Skunks in the library: A path to production for scholarly R\&D. Journal of Library Administration, 53(1), 53-66. doi:10.1080/01930826.2013.756698 [Taylor \& Francis Online]

16. Polger, M. A., \& Okamoto, K. (2013). Who's spinning the library? responsibilities of academic librarians 
who promote. Library Management, 34(3), 236-253. doi:10.1108/01435121311310914

17. Potter, N. (2012). Marketing your library... Terry Kendrick. American Libraries, 43(11), 50-52.

18. QS World University Rankings, 2015/16. Retrieved 1 Feb. 2016 from

http://www.topuniversities.com/qs-world-university-rankings

19. Research Libraries UK (2014). Unique and distinctive collections: opportunities for research libraries. Retrieved 1 Feb. 2016 from http://www.rluk.ac.uk/wp-content/uploads/2014/12/RLUK-UDC-Report.pdf

20. Robinson, C. K. (2012). Peter Drucker on marketing: Application and implications for libraries doi:10.1108/08880451211229153

21. Saunders, L. (2015). Academic libraries' strategic plans: Top trends and under-recognized areas. Journal of Academic Librarianship, 41(3), 285-291. doi:10.1016/j.acalib.2015.03.011

22. Stoffle, C. J. \& Cuillier, C. (2011). From surviving to thriving. Journal of Library Administration, 51(1), 130-155. doi:10.1080/01930826.2011.531645

23. Stoffle, C. J., Leeder, K. \& Sykes-Casavant, G. (2008). Bridging the gap: Wherever you are, the library. Journal of Library Administration, 48(1), 3-30. doi:10.1080/01930820802028948

24. Vandegrift, M. \& Varner, S. (2013). Evolving in common: Creating mutually supportive relationships between libraries and the digital humanities. Journal of Library Administration, 53(1), 67-78. doi:10.1080/01930826.2013.756699

25. Vinopal, J. \& McCormick, M. (2013). Supporting digital scholarship in research libraries: Scalability and sustainability. Journal of Library Administration, 53(1), 27-42. doi:10.1080/01930826.2013.756689

26. Wade, M. (2013). Re-inventing the library: the role of strategic planning, marketing and external relations, and shared services at the National Library of Scotland. Library Review, 62(1), 59-66.

doi:10.1108/00242531311328177

27. Walton, Geoff \& Cleland, Jamie (2013). Becoming an independent learner in Secker, Coonan (Eds), Rethinking information literacy: a practical framework, pp13-26. London, Facet 